3. Harries E. W. Twice upon a Time Women Writers and the History of the Fairy Tale. Princeton University Press, 2001. 317 p.

DOI https://doi.org/10.30525/978-9934-26-073-5-1-12

\title{
ФУНКЦІОНАЛЬНО-СЕМАНТИЧНЕ ПОЛЕ ПРИБЛИЗНОЇ КІЛЬКОСТІ У ГОВІРКАХ БУКОВИНИ
}

\author{
Попович Н. М. \\ кандидат філологічних наук, \\ доиент кафедри історії та культури украӥнської мови \\ Чернівецького національного університету імені Юрія Федьковича
}

\author{
Філіпчук М. В. \\ кандидат філологічних наук, \\ дочент кафедри історії та культури украӥнської мови \\ Чернівецького національного університету імені Юрія Федьковича \\ м. Чернівиі, Україна
}

Увагу дослідників здавна привертала проблема використання впорядкування різнорівневих одиниць мови, об'єднаних спільним значенням (О. Есперсен, В. Адмоні, І. Мещанинов та ін.). В останні десятиріччя у зв'язку з активізацією функціонального підходу до вивчення мовної системи почали дедалі ширше використовувати польову методику. Суть іiі полягає в об'єднанні різноструктурних мовних засобів у функціонально-семантичне поле (ФСП), що грунтується на спільній семантичній ознаці. Розгортання досліджень з функціональної граматики уможливило аналіз мовної категорії квантитативності як функціональносемантичної категорії чи функціонально-семантичного поля, тобто систематизацію одиниць усіх рівнів мови, що виражають різні кількісні значення за категорійним або польовим принципом.

Велике число досліджень, проведених 3 позицій функціонального підходу, в яких різнорівневі засоби мовної репрезентації понятійної категорії кількості систематизовані у вигляді функціонально-семантичних полів, виконано на матеріалі англійської мови (В. Акуленко, С. Жаботинська, С. Кабанова, I. Кошова, С. Швачко, О. Медвідь, Н. Чернюк), німецької (В. Адмоні, С. Гулига, С. Шендельс, Л. Акуленко), російської (О. Бондарко, І. Тимофєєв, В. Панфілов, Л. Чеснокова). 
В українському мовознавстві здобутки в цій галузі скромніші. Останні десятиріччя позначені активною увагою вчених до проблем семантичного аналізу квантитативних компонентів. Значеннєвий потенціал цих одиниць неодноразово ставав предметом вивчення. Особлива увага була приділена числівнику - основному виразникові квантитативної семантики (К. Городенська, І. Вихованець, О. Межов, А. Загнітко та ін.). В останнє десятиріччя спостерігаємо розгортання досліджень саме в руслі функціонально-семантичного поля кількості. З'явилися дисертаційні дослідження: С. Бронікової «Функціонально-семантичне поле квантитативності в сучасній українській мові» (2004), О. Семененко «Функціонально-семантичне поле неозначеної кількості в українському поетичному дискурсі» (2011), а також статті: С. Шабі «Структура лексико-семантичного поля кількості у мові української казки» (2009), «Номени неконкретизованої квантитативності у структурі лексикосемантичного поля кількості української казки (2011)», С. Баранова «До історії питання про квантитативність та квалітативність» (2009); ««Філософія» кількісно-якісних відношень» (2012), Л. Марчук «Варіанти квантитативних структур як відображення різних пізнавальних стратегій авторів сучасної української прози» (2013).

I все ж структурування функціонально-семантичних полів на основі кількісних значень в українському мовознавстві розроблене ще недостатньо, а тому воно й досі залишається актуальним і відкритим для подальшого вивчення. Тому саме ми обрали для свого дослідження функціонально-семантичне поле приблизної кількості.

Приблизна кількість розташована на периферії семантичного поля кількості і утворює своє мікрополе, хоч у мовній практиці приблизну кількість інколи ототожнюють 3 неозначеною кількістю. Тому на цьому питанні зупинимося докладніше. Мабуть, буде помилково ставити між ними абсолютний знак рівності. Логічніше буде, якщо приблизній кількості відвести проміжне місце на антонімічній осі «означена (точна) кількість - неозначена кількість». Приблизна кількість - це неточна кількість, яка від неозначеної кількості відрізняється тим, що показує максимальну ймовірність точної кількості. Як вважає Л. Чеснокова, поняття приблизної кількості співвідноситься з об'єктивною дійсністю, відбиваючи, з одного боку, близькість даної кількості до деякої точної кількості, яка є фактом реального світу; з іншого боку, приблизність являє собою особливу форму осмислення кількісних відношень і $є$ чисто гносеологічною категорією [5, с. 28].

Елемент приблизності притаманний самому процесу спілкування, так як повсякденне життя не завжди вимагає охарактеризувати предмет 
точно, в результаті чого людина часто оперує неточними поняттями i категоріями. Приблизна кількість тісно пов'язана 3 ідеєю близькості, і в цьому полягає ії специфіка.

Отже, категорія приблизності 3 семантичної погляду неоднорідна і утворює систему кількісних значень, серед яких дослідники виділяють ряд різновидів.

Л.Чеснокова, наприклад, виділяе чотири приватних значення приблизності: вказівка на початкову межу, вказівка на кінцеву межу, вказівка на кількісний проміжок, вказівка на середню точку відліку [5].

За нашими спостереженнями, у буковинських говірках категорія приблизності 3 семантичного погляду утворює систему наступних кількісних значень. Мікрополе приблизної кількості має кілька способів вираження. Найтиповішими є використання лексичних модифікаторів на зразок зо, з, до. Напр.: Приниси й міні кужів, най напріду зо пару валовиц (Слобідка Глиб., С. 46); То шо підиш уже жовнєрувати, ци ще пускає з на nару місіиів? (Старий Вовчинець Глиб., С. 118); Ану, сподні надолину, най я тобі дам зо два, бис знав, як мами не слухатиси (Слобідка Глиб., С. 310); Зроби хоть зо три мідівники (Ожеве Сок., С.173); Шя лишилоса зо дві кавулі, й білши нима (Козиряни Кельм., С. 180); Неньо за вечир с криги злапали зо сім кил риби (Мусорівка Заст., С. 167-168); Славко думає кликати з до сто пар гостий (Старосілля Кіцм., С.164); Відійшли зо два кроки, лід як запукав, а він назад (Коритне Вижн., С. 140); Запізнив'імси, можи, зо десєть мінут, а заводив мині за то зо тиждень (Старосілля Кіцм., С. 126); Тут насіні є з на дві ділянці нима чо журитиси (Дорошівці Заст.); То який політок, али я с такого кавальчика збирав з до трьох кориів помідорів (Самушин Заст., С. 120); Купи зо дві дури, бо нема чим світити (Козиряни Кельм., С. 105); От дам тобі зо дві головиці, й будиш знати, як прозиватиса (Козиряни Кельм., С.73); Віттів до нас буде з десіть кіломитрів (Старосілля Кіцм., С. 55); Е-еге, ягби мав таких зо шість буськів горівки, то чо би я хотів (Долиняни Хот., С. 41); Того тижня у Сиреті я набив остами зо десіmь щукк (Комарівці Стор., С. 369); Я клав зо шттири клані на лойтир (Романківці Сок., С. 264); Як ззів зо три лодi за раз, аж горло задиривіло (Великий Кучурів Стор., С. 264); С цеї ломаги буди з наруч дров (Кам'яна Стор., С. 264); Урви зо скілька мичок трави кроликам (Долиняни Хот., С. 290); Мині траба ще з десіть латин (Сторожинець, С. 254).

Приблизна кількість зі значенням «більше або дорівнює одній точці відліку і менше або дорівнює іншій точці відліку». Ця приблизна кількість виражається поєднанням двох числівників (два-три; n'ятьuість; щ⿻о два, а щзо три; два або три; два чи три). Напр.: Цилько 
ззагорічу ще ступив зо два-три кроки, а потому пішла кров ротом і впав (Лужани Кіцм., С. 163); Петро такий до науки, шо єму однака оцінка шо два, а шо п'ять (Пашківці Хот., С. 362); Нелічені вмирают оден раз, а лічені - два або й три (Хлівище Кіцм., С. 329); Потом буряк ділят, це проривают йго, лишают шість-сім рослин на метр (Романківці Сок., С. 96); Це ше покійний вуйко уповідав, шо там людности мало і село від села на дві-три милі (Старосілля Кіцм., С. 268); Верьх дерива пиля на куцаки, котрі мают митир або два (Юрківці Заст., С. 245); Свіже молоко цідя на сітівку, а воно посидит два чи три дни і ловиси на кисле (Ярівка Хот., С. 264).

Приблизна кількість із значенням «менше точки відліку». Напр.: Рая, як була май молода, то обтикала і коверцами, i торбинами, і поясами майже півсела (Старосілля Кіцм., С. 356).

Приблизна кількість виражається у говірках Буковини словами може, хоть, коло, до. Напр.: На все село у нас може є дві мадіски (Лукачівка Кельм., С. 273); Лупак продают лиш друбний, а тесаного каменю бири хоть і п'ять кубів (Ленківці Кельм., С. 266); Оден мотовилник тканя мав коло шттири метри (Рідківці Нов., С. 297); Де типер так си мучі жінки, як колис, до ста ладінок спрідали за зиму, а ще кілько клочі! (Борівці Кіцм., C. 249).

Отже, приблизна кількість у говірках Буковини має свою особливість. Ядро функціонально-семантичного поля приблизної кількості становлять числівники з лексичними модифікаторами на зразок зо, з, до, коло, може, хоть. Периферію - з модифікатором майже.

Приблизність пов'язана з тим, що кількість мислиться як деяка множина чисел, близьких до обраної точки відліку. При цьому мовець вважає, що якесь одне 3 цих чисел безперечно відповідає його дійсним даним, і тому в цілому думка про кількість супроводжується ідеєю сумніву. Значення приблизності відрізняється від модального значення невпевненості, припущення. Вони розташовані на різних площинах: значення приблизності розкриває кількісно оцінку в плані близькості повідомлюваної кількості до тієї чи іншої точки відліку, а значення здогадності розкриває оцінку в плані достовірності/недостовірності повідомлюваного.

\section{Література:}

1. Арполенко Г. П., Городенська К. Г., Щербатюк Г. Х. Числівник української мови. К.: Наук. думка, 1980. 239 с.

2. Безпояско О. К. Іменні граматичні категорії (Функціональний аналіз). К.: Наук. думка, 1991. 169 с. 
3. Вихованець I. Р. Теоретична морфологія української мови: Академ. граматика укр. мови. К.: Унів. вид-во «Пульсари», 2004. 400 с.

4. Граматика сучасної української літературної мови. Морфологія / За ред. К. Г. Городенської. К.: Видавничий дім Дмитра Бураго, 2017. $752 \mathrm{c}$.

5. Чеснокова Л. Д. Категория неопределленного множества и семантические формы мысли // Семантика грамматических форм / Отв. Ред. П. В. Чесноков. Ростов-на-Дону: Изд-во Ростовск. пед. ин-та, 1982. C. 21-31.

6. Словник буковинських говірок / За заг. ред. Н. В. Гуйванюк. Чернівці: Рута, 2005. 688 с.

DOI https://doi.org/10.30525/978-9934-26-073-5-1-13

\section{МОДЕЛЮВАННЯ ФРЕЙМУ ДИКТАТОР НА МАТЕРІАЛІ ОПОВІДАННЯ ОЛЬГИ ТОКАРЧУК «КАЛЕНДАР ЛЮДСЬКИХ СВЯТ»}

\section{Рогальська-Якубова I. I.}

кандидат філологічних наук, стариий викладач кафедри лінгвістичних підготовки Державного університету інтелектуальних технологій та зв 'язку м. Одеса, Украӥна

Фреймовий аналіз $є$ одним 3 популярних методів когнітивної лінгвістики. I хоча засновник теорії фреймів М. Мінський фреймом називав модель стереотипної ситуації, зараз за допомогою методу моделюються також статичні фрейми, фрейми почуттів тощо. Термін використовується для опису типової структури, призначеної організувати певну інформацію. У залежності від змісту впорядковуваної інформації виокремлюються слоти, термінали фрейму. Кількість слотів відповідає кількості елементів, що виділяються в даному фрагменті досвіду, слот має ім'я, яке задає сам параметр, і заповнюється інформацією про значення, що даний параметр приймає у даного типу об'єктів або даного конкретного екземпляра [4, с. 65].

Дослідники виділяють різні слоти фреймів. Наприклад, С.А. Жаботинська пропонує таку фреймову структуру: ЩОСЬ / ХТОСЬ - предмет, ТАКИЙ - якість, ІСНУЄ ТАК - буття, ТУТ / ТАМ - місце, ЗАРАЗ / ТОДІ - час [3, с. 11-12] - об'єктивовану в категоріях частин мови. 